\title{
Pea and rapeseed acreage and land use for plant-based meat alternatives in the $\mathrm{EU}^{\text {is }}$
}

\author{
Etienne Pilorgée ${ }^{2, *} \oplus$, Bruno Kezeya ${ }^{1}$, Wolfgang Stauss ${ }^{1} \oplus$, ${\text { Frédéric } \text { Muel }^{2} \text { and Marcus Mergenthaler }}^{1}$ \\ ${ }^{1}$ South Westphalia University of Applied Sciences, Lübecker Ring 2, 59494 Soest, Germany \\ 2 Terres Inovia, Avenue Lucien Brétignières, 78850 Thiverval-Grignon, France
}

Received 2 February 2021 - Accepted 21 October 2021

\begin{abstract}
Plant-based meat alternatives from grain legumes and oil crops are expected to play an increasing role in human nutrition. Several commercially available products use pea protein isolate as protein basis and rapeseed oil as lipid basis. The aim of the present study is to estimate the prospective area of peas and rapeseed for plant-based meat alternatives in the EU. A simple calculation model is employed to assess the impacts on land use and imported deforestation, in case plant-based meat alternatives substitute meat consumption in different shares. Various data sources and scenarios were used to estimate the cultivation potential. While pea acreage would increase considerably compared to current production, additional rapeseed acreage would be more limited. Even in an extreme scenario of $100 \%$ substitution only $12 \%$ of EU's arable land would be used for pea and rapeseed as main ingredients for plant-based meat alternative. If pea protein isolate and rapeseed oil as main ingredients of plan-based meat alternatives increase, the land currently used for animal feed production would become partly available and imported deforestation could be decreased: a substitution of $25 \%$ of meat consumption would allow to provide the equivalent of food proteins without extending the cultivated areas in Europe, while avoiding soybean and maize imports for feed.
\end{abstract}

Keywords: cultivation area / legumes / rapeseed / plant-based meat alternatives / pea protein isolate / land use / imported deforestation

Résumé - Superficie des cultures de pois et de colza et utilisation des terres pour les substituts de viande d'origine végétale dans l'UE. Les substituts de viande d'origine végétale issus de légumineuses à graines et de cultures oléagineuses devraient jouer un rôle croissant dans l'alimentation humaine. Plusieurs produits disponibles dans le commerce utilisent l'isolat de protéine de pois comme base protéique et l'huile de colza comme base lipidique. L'objectif de la présente étude est d'estimer la superficie potentielle de pois et de colza pour les substituts de viande d'origine végétale dans l'UE. Un modèle de calcul simple est utilisé pour évaluer les impacts sur l'utilisation des terres et la déforestation importée, dans le cas où les substituts de viande d'origine végétale remplacent la consommation de viande dans des proportions différentes. Différentes sources de données et différents scénarios ont été utilisés pour estimer le potentiel de culture. Alors que la superficie consacrée aux pois augmenterait considérablement par rapport à la production actuelle, la superficie supplémentaire consacrée au colza serait mineure. Même dans un scénario extrême de substitution à $100 \%$, seuls $12 \%$ des terres arables de l'UE seraient utilisés pour les pois et le colza comme principaux ingrédients des substituts de viande d'origine végétale. Si l'isolat de protéines de pois et l'huile de colza comme principaux ingrédients des substituts de viande d'origine végétale augmentaient, les terres actuellement utilisées pour la production d'aliments pour animaux deviendraient en partie disponibles et la déforestation importée pourrait être réduite: une substitution de $25 \%$ de la consommation de viande permettrait de fournir l'équivalent des protéines alimentaires sans étendre les surfaces cultivées en Europe, et en évitant les importations de soja et de maïs pour l'alimentation animale.

Mots clés : zone de culture / légumineuses / colza / substituts de viande d'origine végétale / isolat de protéine de pois / utilisation des terres / déforestation importée

\footnotetext{
is Contribution to the Topical Issue "Creating new oil \& protein crop value chains / Construire de nouvelles filières oléoprotéagineuses"

*Correspondence: e.pilorge@terresinovia.fr
} 


\section{Introduction}

Plant-based meat alternatives from grain legumes and oil crops are expected to play an increasing role in human nutrition (Röös et al., 2018; van der Weele et al., 2019; Aiking and de Boer, 2020). Several commercially available products use pea protein isolate as protein basis and rapeseed oil as the lipid basis. While rapeseed oil cultivation and processing is well established in the EU, pea production and processing are yet emerging. Increasing the availability of proteins from legumes is pursued through increased legume production at the primary production level and advances in food processing within the EU. Especially in organic agriculture legumes play a major role as a $\mathrm{N}$-fixing crop (Schmidt et al., 2012). Yet, the orientation of European agriculture towards the massive production of commodities led to an impoverishment of European cropping systems, with important adverse effects on the sustainability of the agro-ecosystems (Schott et al., 2010). In order to diversify crop rotations, legumes are recommended in conventional agriculture (Magrini et al., 2018). To this end, EU and national policies have provided the framework for several programs and strategies offering incentives for the establishment of more legume cultivation and value-adding (Kuhlman et al., 2014). The aim of the present study is to estimate the prospective area of peas and rapeseed as main ingredients for plant-based meat alternatives in the EU within a simple calculation model. Thereby we aim to assess the impacts on land use and imported deforestation, in case plantbased meat alternatives substitute meat consumption to different degrees. It shows that a total substitution of meat consumption in EU by plant-based substitutes would mobilize around $12 \%$ of the EU arable land for "pea meat" production, and that a substitution of $25 \%$ of meat consumption would allow to provide the equivalent of food proteins without extending the cultivated areas in Europe while avoiding soybean and maize imports for feed at the same time.

\section{Background}

\subsection{Legumes as innovative food ingredient}

Different private and public initiatives have started to develop innovative foods from European legumes like for example faba bean, pea, lupins, lentils and chickpeas or soybean. At the consumption level diverse diets that include legumes make important contributions to healthiness (Foyer et al., 2016). The health benefits of legumes include positive effects on cholesterol levels, decrease diabetes, heart diseases, hypertension and have preventive effects on cancer (Dahl et al., 2012; Madar and Stark, 2002; Trinidad et al., 2010). Although there are possible challenges related to less absorption of some vitamins and low content of some essential minerals and amino acids, diet specialists recommend legume consumption (Baldwin et al., 2017). Food innovations that highlight positive health aspect and more explicit dietary guidelines are relevant steps for increasing consumption of legumes (Figueira et al., 2019; Magrini et al., 2019). More than 3,500 new legume-based products were introduced in the European food market, particularly in the UK, France,
Germany, Spain and Italy in the period 2010-2014, products mainly based on chickpea $(31 \%)$, pea $(30 \%)$, beans $(25 \%)$, lentils (14\%), of which only $13 \%$ are organic (Hamann, 2019). In 2016, the consumption of pulses per person per year in Europe was on average $3 \mathrm{~kg}$, but with large variations between countries (Hamann, 2019).

At the opposite, the diets in Europe are relatively rich in meat (Tab. 1): $68.6 \mathrm{~kg}$ /capita in 2017, with internal differences of quantities and composition between regions of EU, when the consumption is $34.5 \mathrm{~kg} /$ capita at world level, from 26.6 in developing countries to 69.3 in OECD countries (OECD/FAO Outlook 2020-2029, as retail weight).

Protein flours, concentrates and isolates from legumes are used in an increasing number of innovative food products having the potential to partly replace meat and dairy products (Singhal et al., 2016). Protein meals and isolates from legumes have the potential to improve the protein content of traditional flours in the baking industry to sustain the functional properties of traditional flours with low protein contents (Turfani et al., 2017). Innovative food products also include a whole range of products based on legume protein such as vegan ice cream or vegan yoghurts (e.g. Lim et al., 2019) and drinks (Qamar et al., 2019; Lopes et al., 2020; Nawaz et al., 2020; Verni et al., 2020). Also a high diversity of spreads has been and is being developed. In addition, low-carb diets depend on protein rich ingredients for which legume-based protein meals and isolates can be used. Additionally, ingredients in food supplements for sportspeople have been introduced. Direct meat and sausage imitates depend on plant-based protein alternatives for which legumes function as important alternatives (Joshi and Kumar, 2015; Dreher et al., 2020; Sha and Xiong, 2020). Some of the innovations are already in the market but constitute only small market shares. Other legume-based food products are still in the R\&D pipeline with possible market potential (Murphy-Bokern et al., 2019).

\subsection{Plant-based meat alternatives}

Peas play an important role in human and animal nutrition in the EU, whereby the use for feed dominates. Within the EU countries, the share for food and feed can be totally different. While $36 \%$ of the national consumption of peas are used for food in Germany, it is more than $80 \%$ in the UK (Kezeya Sepngang, 2019). According to Eurostat, pea is the second most produced grain legume in the EU with a production of 2 Mio.t, after soybeans, 2.9 Mio.t in 2018. The trend of pea production in the EU is increasing. This increased production during the last five years is partly due to the Common Agricultural Policy (CAP) implemented in 2015 that consider legumes' growing areas as ecological focus areas (Wobser, 2018). The leading producers of pea in the EU are France, Germany, Lithuania, Spain, Romania and UK. These countries represent more than $75 \%$ of the EU production.

The US-based company Beyond Meat is a major innovator in plant-based meat alternatives. Beyond Meat entered the EU retail market in the UK, the Netherlands and Germany with a pea-based vegan burger patty in 2019 which is seen as accelerating the trend towards plant-based meat alternatives in the EU (Bloomberg, 2019; Reuters, 2019). Comprehensive 
Table 1. Average consumption of meats in EU 28, and differences between EU15 (Member States before 2004) and EU13 (States joining EU after 2004).

\begin{tabular}{lllll}
\hline Type meat (kg r.w.e.) & Beef and veal meat & Sheep and goat meat & Pigmeat & Poultry meat \\
\hline Per capita consumption & 10.8 & 1.8 & 31.9 & 24.1 \\
Of which EU-15 & 12.6 & 2.1 & 31 & 68.6 \\
Of which EU-N13 & 3.9 & 0.7 & 35.5 & 24.1 \\
\hline
\end{tabular}

Source: EU Agricultural Outlook for the Agricultural markets and income 2017-2030. EU Commission, 2017, table 9.27-9.30.

*r.w.e.: retail weight equivalent; coefficients to transform carcass weight into retail weight are 0.7 for beef and veal, 0.78 for pigmeat and 0.88 for both poultry meat and for sheep and goat meat.

advantages of the Beyond Meat patties over patties from US beef production were found in a life-cycle assessment by Heller and Keoleian (2018). Pea protein isolate is the protein basis of the Beyond Meat burger patty (Beyond Meat, 2019a, $2019 b$ ). The raw material basis for the protein isolate is assumed to be peas from the northern states of the US and from Canada (Bloomberg, 2019; Heller and Keoleian, 2018). Additional cultivation areas and additional general cultivation potential for peas are forecasted for the short to medium term (Bloomberg, 2019; Reuters, 2019). European peas may become increasingly relevant as raw materials in the future if the expected market growth evolves with a regional origin of the raw materials. This would result in additional sales potential for EU legume producers with growing cultivation areas. The French company Roquette's partnership with Beyond Meat gives an indication of the strategic supply development (Beyond Meat, 2020). Increase production of plant-based meat alternatives has consequences for pea production and transforms the food sector as pea-based meat alternatives have further synergies with the vegetable oils sector.

The Beyond Meat patties are made of the following ingredients: water, pea proteins and rice proteins for the protein fraction, coconut oil and rapeseed oil for the lipid fraction, potato starch and methylcellulose for carbohydrates, plus minerals and natural flavors (source: Beyondmeat.fr website, December 2020). The European Union is also a producer of vegetable oils from diverse crops species, mainly rapeseed (the winter type equivalent of canola), sunflower and soybean, and evident synergies with the oil sector would appear in case of "pea meat" development. Natural meat contains significant quantities of lipids, sometimes called "hidden lipids", mostly as saturated and mono-unsaturated fats (see ANSES, 2020 - French food composition table at https://ciqual.anses. $\mathrm{fr} / \#)$. Lipids are necessary both for nutritional value and for taste, and a vegetable meat formula must include a reasonable amount of lipids.

\subsection{Data and methods}

A simple calculation model is employed to assess the impacts on land use and imported deforestation, in case plantbased meat alternatives substitute meat consumption in different shares. Various data sources were used to estimate the cultivation potential of peas and rapeseed for the production of "pea meat". In our analysis here, "pea meat"
Table 2. Nutritional comparison of beyond burger and $80 / 20$ beef.

\begin{tabular}{lcc}
\hline & $\begin{array}{c}\text { Beyond burger } \\
\text { 4 oz BB patty } 4 \mathrm{oz}\end{array}$ & $\begin{array}{l}80 / 20 \text { beef } \\
\text { (USDA, 2015) }\end{array}$ \\
\hline Weight (g) & 113 & 113 \\
Protein (g) & 20 & 19 \\
Cholesterol (mg) & 0 & 80 \\
Total fat (g) & 22 & 23 \\
Saturated fat (g) & 5 & 9 \\
Unsaturated fat (g) & 17 & 14 \\
Calories & 290 & 287 \\
Iron (DV) & $25 \%$ & $12 \%$ \\
\hline
\end{tabular}

is defined as a plant-based alternative to animal meat based on field pea protein and vegetable oils fatty acids. The calculation model assumes the same proportion of peas and rapeseed utilized for the Beyond Meat patty also for "pea meat" in general. In this way the amount of peas and rapeseed for a certain amount of "pea meat" can be calculated. Based on average yields of peas and rapeseed the required cultivation area can be derived. We assume constant pea and rapeseed yields as well as constant protein and oil content in our model although this might change with increased breeding efforts. In the calculation, plausible assumptions were made in case of unavailable data.

As the share of rapeseed oil is not given in the list of ingredients, we have to calculate this share. The nutritional composition of Beyond Meat burger as reported in Heller and Keoleian (2018) is given in Table 2.

The presence of coconut oil is probably linked to technological constraints and functional qualities of saturated oils to make a more solid or palatable product. To evaluate the rapeseed oil content, we have to focus on the lipid composition, and consider that coconut oil and rapeseed oil contain $84.5 \%$ and $7.4 \%$ saturated fatty acids, and $14 \%$ and $91.4 \%$ unsaturated fatty acids respectively. These average compositions may be sufficient for a basic evaluation of the respective shares of coconut oil and rapeseed oil since no other ingredient contains lipids or fats. We have a system of two equations with two values to determine: if $\mathrm{C}$ is coconut oil weight and R Rapeseed oil weight, $\mathrm{C} \times 0.845+\mathrm{R} \times 0.074=5 \mathrm{~g}$ and $\mathrm{C} \times 0.14+\mathrm{R} \times 0.914=17 \mathrm{~g}$, leading to $\mathrm{C}=4.347 \mathrm{~g}$ and $\mathrm{R}=17,933 \mathrm{~g} /$ patty. Let us consider on the basis of the 
previous assumptions that $17.9 \mathrm{~g}$ of rapeseed oil per patty are needed. On the basis of this figure, we can complete the calculations made for peas acreage by calculating the corresponding rapeseed acreage, using average rapeseed yields in Europe.

The calculation model is described in Table 3, with assumed parameter values and respective sources; it has been developed as a spreadsheet and does not consider feed-back interactions.

The pea protein isolate quantity and the pea equivalent quantity per patty can be calculated based on the weight of the "pea meat" burger patty, the proportion of pea protein isolate in the recipe and the pea protein content in peas as well as in the pea protein isolate. If the pea equivalent quantity per patty is set in relation to the pea yield, the necessary pea cultivation area for one "pea meat" burger patty is obtained. In the same way the quantity of rapeseed oil per patty together with the exploitation rate of oil can be used to derive the equivalence quantity of raw rapeseed per patty. If this quantity is set in relation to rapeseed yields, the rapeseed area per patty can be calculated (Tab. 4).

To estimate future consumption shares, an expert panel was interviewed as part of the European joint project LegValue. Thirty-one of the 42 participants in the annual project meeting in 2019 answered the following question in a smartphonebased online survey: "What is your estimate of the percentage share of EU "vegan meat" consumption from European legumes in 2030?" Minimum, median, maximum values from the survey were respectively $2 \%, 12.5 \%$ and $40 \%$. More extreme value of $50 \%, 75 \%$ and $100 \%$ were used as the basis for calculations for the EU.

\section{Results}

\subsection{Quantity and area effects of plant-based meat alternative development}

Based on per capita consumption of animal meat, consumption volumes of "pea meat" can be estimated. Four scenarios are assumed for the annual consumption of "pea meat" with consumption shares of $2 \%, 12.5 \%, 50 \%$ and $75 \%$ of the animal meat consumption of $64 \mathrm{~kg}$ per capita per year in the EU. This makes it possible to estimate corresponding consumption quantities for the total population in EU (Fig. 1). The pea protein isolate content in the recipe and the pea protein yield can be used to calculate the required pea quantity. If this is set in relation to the pea yield, the required pea cultivation area is obtained. This can be set in relation to the previous pea cultivation area or to the total arable land of approximately 103 million ha in the EU. In the same way the above calculated rapeseed oil content and the oil yield can be used to calculate the required rapeseed quantity. This quantity can be set in relation to rapeseed yields to derive the required rapeseed cultivation area (Fig. 2).

The expeller pression of oilseeds (and not extraction) is mentioned in the ingredients list: we estimated the oil extraction rate to $39 \%$ oil, for an average oil content in seeds of $43 \%$, considering a remaining $6 \%$ oil in expeller cakes corresponds to a current level for oil industries, but this depends on the conditions of the process (cold/hot, more or less pressure). It may reach up to $12 \%$ oil remaining in meals. A difference of one point on extraction rate (for example $38 \%$ instead of $39 \%$, corresponding to $8.7 \%$ oil remaining in meals), leads to a difference of $2.6 \%$ on acreages $(+13,700$ ha for $12.5 \%$ scenario). At last, it must be added that the classical solvent extraction leaves no more than $3 \%$ oil in meals, which could lead to lower acreages. Nevertheless, expeller pression brings a better image of the product for consumers.

The final result of the calculation, adding pea and rapeseed acreages shows that, in theory, about $11.5 \%$ of the EU 28 arable land would be needed, with the present yields, for a complete substitution of animal meat by pea-based products for direct food consumption. This conclusion is relatively robust in case of yields evolutions: within a range of $-20 \%$ to $+20 \%$ compared to the present pea and rapeseed average yields to share of EU arable land would represent from $9.6 \%$ to $14.4 \%$ (Fig. 3).

The next step of our theoretical calculation is to assess the potential effect on land use in Europe, under the assumption that all the feed quantities would be produced in Europe, including cereals, fodders and soybean. A similar calculation could be done to assess the effect on imported deforestation, on the basis of soybean yields in Brazil.

\subsubsection{Effects on general EU feed consumption and land use}

To assess the potential effect of "pea meat" substitution on land use, we have to consider on one side the acreage needed for "pea meat" production, and on the other side, the acreage needed to produce the feed for animal husbandry. For a simple and general approach, we work on sectoral statistics, starting from the total feed consumption statistics obtained from the EU Agricultural Outlook 2017-2030 (2015/2016 data), which is affected to each animal category (Tab. 5)

The EU protein balance sheet published by the EU Commissions gives a higher total of $266 \mathrm{MT}$ for ingredients of vegetable origin, probably due to other animal productions like aquaculture or petfoods. If we compare these statistics with FEFAC (2018) (European Feed Industries) statistics, we can see that the compound feed industries produced $156 \mathrm{MT}$ of feed, i.e., $59 \%$ of the total feed consumption in EU28, of which 7.9 MT for other animal categories than poultry, cattle and pigs. If we assume a similar share of on-farm-made feed for these other categories, the total amount for EU would be 13.4 MT. Added to 253.2, the result is $266.6 \mathrm{MT}$, consistent with the statistics of the European Commission (2019) for the total vegetable ingredients for feed uses (Tab. 6): 265.6 MT in $2015 / 2016$ and 266.4 MT in 2017/2018.

We shall keep the amount of 253 million tons for the productions related to meat production and have to make two adjustments:

- this feed consumption includes dairy and eggs productions: we shall make the assumption that $15 \%$ of the consumption is affected to meat production in the case of dairy cows, and $25 \%$ in the case of laying hens, on the total life duration of these animals (Flysjö et al., 2011; Mackenzie et al., 2017). The compound feed consumption table for meat production is then adjusted as follows, giving a total feed amount of 205 million tons/year (Tab. 7):

- we must readjust these data proportionally to the net meat consumption in EU, and cancel the quantities corresponding 


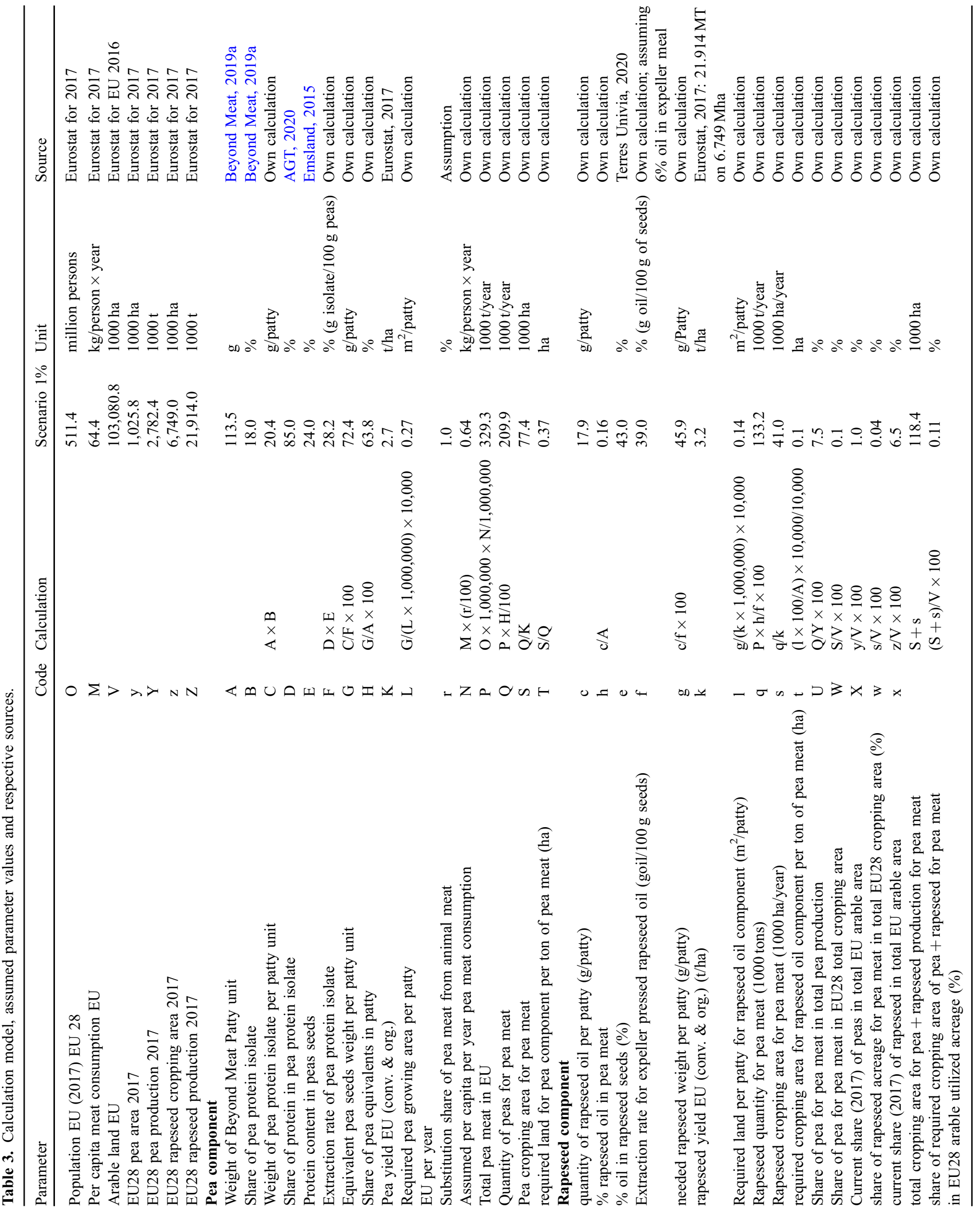


Table 4. Calculated parameter values set in relation to one pea patty.

\begin{tabular}{ll}
\hline Parameters & Value \\
\hline Peas & \\
Quantity of pea protein isolate & $20.43 \mathrm{~g} / \mathrm{patty}$ \\
Exploitation rate of pea protein isolate from & $28.2 \%$ \\
raw peas & \\
Equivalence quantity of raw peas per patty & $72.36 \mathrm{~g} / \mathrm{patty}$ \\
Pea area per patty & $0.27 \mathrm{~m}^{2} / \mathrm{patty}$ \\
Rapeseed & \\
Quantity of rapeseed oil & $17.90 \mathrm{~g} / \mathrm{patty}$ \\
Exploitation rate of rapeseed oil from raw rapeseed & $39.0 \%$ \\
Equivalence quantity of raw rapeseed per patty & $45.90 \mathrm{~g} / \mathrm{patty}$ \\
Rapeseed area per patty & $0.14 \mathrm{~m} / \mathrm{patty}$ \\
Total & \\
Required pea and rapeseed area per patty & $0.41 \mathrm{~m} / \mathrm{patty}$ \\
Required pea and rapeseed area per ton of & $0.36 \mathrm{ha} / \mathrm{t}$ \\
"pea meat" & \\
\hline
\end{tabular}

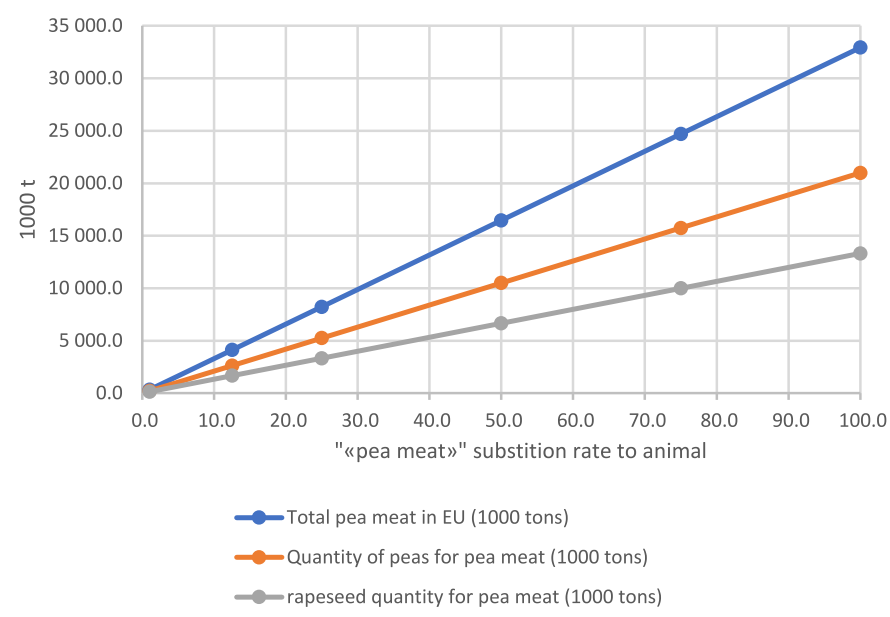

Fig. 1. Evolution of quantities of "pea meat" consumption in EU28 and needed pea and rapeseed quantities (1000 tons).

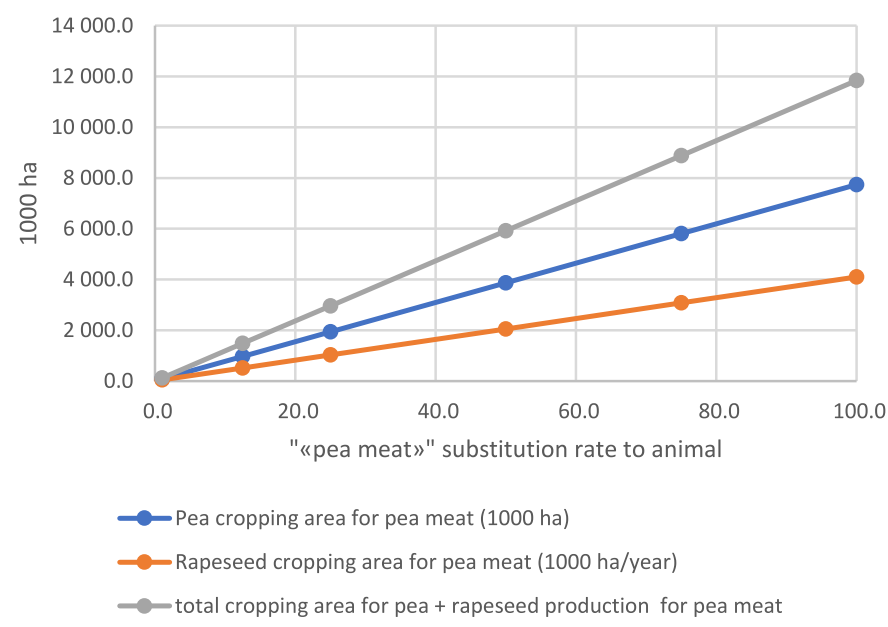

Fig. 2. Evolution of acreage for pea and rapeseed production for "pea meat" (1000 ha) according to "pea meat" substitution rate.

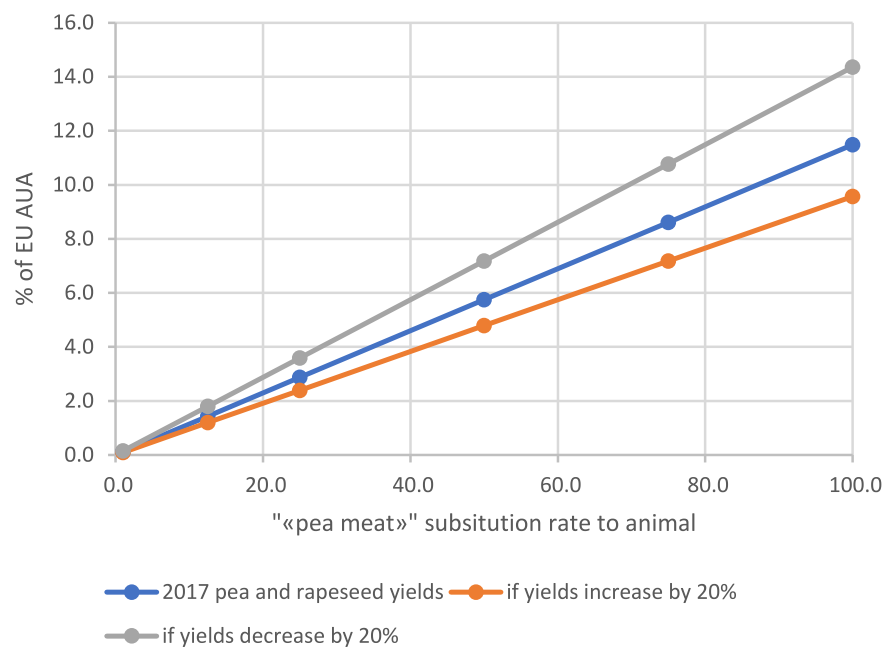

Fig. 3. Share of required cropping area of pea + rapeseed for "pea meat" in EU 28 arable utilized acreage (\%).

to meat exports. Thereby we assume that self-sufficiency of $100 \%$.

Table 8 details the next calculation steps: to convert tons of feed in ha, we use the 5 years average crop yield for the main concerned crops: common wheat, barley, maize, rapeseed, sunflower and soybean (average weighted with respective acreages), which reflects the average potential of arable crops in EU. Taking into account fodder crops is simpler since these surfaces are devoted to animal husbandry only. We assume that "pea meat" substitutes in an equal proportion all animal meats from different animal species: substituting $1 \%$ of EU meat consumption means substituting $1 \%$ of beef meat, of pork meat and poultry meat. We assume that $1 \%$ reduction of animal meat consumption leads to $1 \%$ reduction in animal production and feed consumption.

This rough calculation leads to a need of 0.570 million ha to produce $1 \%$ of the EU meat consumption. If we consider that "pea meat" production will engage 0.119 million ha, the net balance is -0.451 million ha, meaning that $100 \%$ substitution would be equivalent to 45.1 million ha, that is to say comparable to the present cereal acreage in Europe (56 Mha on 2015-2019 period, on a total arable area of $104 \mathrm{Mha})$. Of course, only a part of this land would be made free in Europe, since a large part corresponds to imported proteins as soybean or soybean meal, and imported maize (see Tab. 6), the EU being a net exporter of cereals, but a net importer of maize.

\subsubsection{Producing soybean in Europe?}

As shown by Guilpart et al. (2020), in terms of agronomy, $100 \%$ soybean self-sufficiency in Europe would be feasible even in a climate change perspective, and under the respect of basic agronomic rules (1 soybean every 3 to 6 years depending on the scenarios considered, priority choice to the best climatic zones).

Considering the present soybean yields in European Union of 2.9t/ha (non GMO cultivars) (OilWorld, 2019/2020), 10.4 Mha would be needed to meet the needs of cattle, poultry 
Table 5. EU compound feed use in million tons (from EU Agricultural outlook 2017-2030 graph 2.47).

\begin{tabular}{|c|c|c|c|c|c|c|}
\hline $2015 / 2016$ & Laying hens & Dairy cattle & Broilers & Beef Cattle & Pork & Total \\
\hline Barley & 0.6 & 6.4 & 3.9 & 10.6 & 17.0 & 38.5 \\
\hline Maize (grain) & 4.5 & 5.2 & 13.6 & 11.5 & 19.4 & 54.2 \\
\hline Wheat & 5.5 & 6.7 & 14.2 & 10.0 & 20.3 & 56.7 \\
\hline Other & 7.3 & 19.4 & 12.7 & 13.7 & 24.2 & 77.3 \\
\hline
\end{tabular}

Table 6. Data from the EU28 Balance Sheet for protein feed 2015/2016.

\begin{tabular}{|c|c|c|c|c|}
\hline CROPS & 177.8 & 161 & 16.8 & 91 \\
\hline Cereals & 173.4 & 156.7 & 16.7 & 90 \\
\hline Maize & 57.3 & 47.1 & 10.2 & 82 \\
\hline Other cereals & 60.6 & 58.3 & 2.3 & 96 \\
\hline Oilseeds & 1.4 & 1.4 & 0 & 100 \\
\hline Co-products & 87.9 & 47.1 & 40.8 & 54 \\
\hline Oilseed meals & 54.5 & 15.8 & 38.7 & 29 \\
\hline Soy meal & 31 & 0.9 & 30.1 & 3 \\
\hline Rapeseed meal & 13.5 & 11.4 & 2.1 & 84 \\
\hline Other co-products & 36.6 & 31.5 & 5.1 & 86 \\
\hline Non-plant sources & 8.8 & 8.6 & 0.2 & 98 \\
\hline Grass & 986 & & & \\
\hline Silage maize & 227 & & & \\
\hline
\end{tabular}

Table 7. EU compound feed use for meat production in million tons (from EU Agricultural outlook 2017-2030 and own calculation).

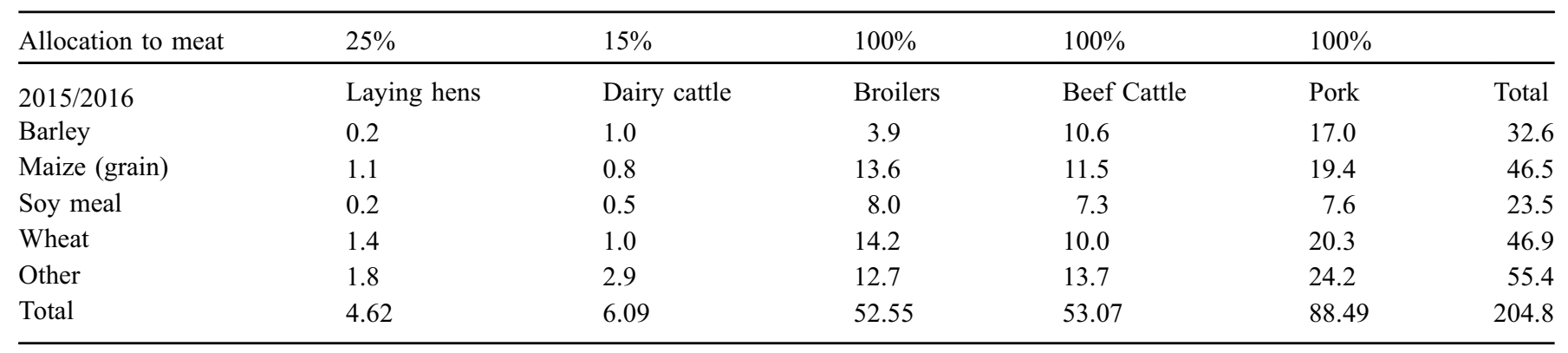

and pork sectors (Tab. 7; 23.5 MT meal, equivalent to 29.4 MT seeds) for internal EU meat consumption, and 13 Mha would be needed -13.36 Mha including the quantities already produced in Europe - to meet the needs of all animal sector (Tab. 6).

For grain maize, 10.2 MT were imported in 2015/2016 (importations are growing) on a total need of 57.3 MT for the all animal sector (18\%). The maize consumption for cattle, poultry and pork sectors only being $46.5 \mathrm{MT}$, the corresponding imported maize quantity would reach $8.28 \mathrm{MT}$, equivalent to
1.10 Mha in EU (5 years average 2015-2019 EU maize yield= $7.5 \mathrm{~T} / \mathrm{ha}$ ). As EU is a net exporter of other cereals, we may take into account soybean and maize only: $10.1+1.1=11.2$ Mha are needed in Europe to compensate soybean and maize imports for cattle, poultry and pork meat internal consumption.

A complementary question is "what would be the substitution ratio of "pea meat" to animal meat which would allow to avoid soybean and maize imports and keep the same acreage devoted to feed production in EU?" We have estimated the total acreage devoted to feed production for cattle, poultry 
Table 8. Calculation model for conversion of feed quantities in cultivated acreage in Europe.

\begin{tabular}{|c|c|c|c|}
\hline & Value & Unit & Calculation formulas \\
\hline EU meat consumption/production ratio & 0.929 & $\%$ & $\mathrm{~B}$ \\
\hline Average dry matter crop yield in Europe & 5,390 & $\mathrm{t} / \mathrm{ha}$ & $\mathrm{C}$ \\
\hline Acreage necessary for the compound feed production & 35,321 & Million ha & $\mathrm{A} \times \mathrm{B} / \mathrm{C}^{*}$ \\
\hline Total fodder crops & 21,700 & Million ha & $\mathrm{D}$ \\
\hline Total fodder and grassland & 79,900 & Million ha & $\mathrm{D}+\mathrm{E}$ \\
\hline Total arable land for feed + fodder & 57,021 & Million ha & $\mathrm{A} \times \mathrm{B} / \mathrm{C}+\mathrm{D}$ \\
\hline Substituting $1 \%$ animal products on arable crops acreage & -0.570 & Million ha & $(\mathrm{A} \times \mathrm{B} / \mathrm{C}+\mathrm{D}) \times 0.01$ \\
\hline Acreage necessary for "pea meat" (pea + canola) to substitute $1 \%$ & 0.119 & Million ha & $\mathrm{F}^{* *}$ \\
\hline Difference of land occupation if $1 \%$ substitution & -0.451 & Million ha & $(\mathrm{A} \times \mathrm{B} / \mathrm{C}+\mathrm{D}) \times 0.01+\mathrm{F}$ \\
\hline $1 \%$ applied on permanent grassland & -0.582 & Million ha & $\mathrm{E} \times 0.01$ \\
\hline
\end{tabular}

Sources: A: Table 7, based on EU Balance sheet for protein and EU Agricultural outlook 2019; B: sum all kinds of meat; Tables 9.27 to 9.30 of EU Agricultural Outlook for the Agricultural markets ad income 2017-2030. EU Commission 2017; C: Eurostat, 5 years average 2015-2020 of cereals and oil seeds, weighted by acreages; source EU agricultural outlook 2019; *: fodder crops not considered; D: EU Agricultural outlook 2017-2030 for 2017; E: EU Agricultural outlook 2017-2030 for 2017; ** (Tab. 3)

and pork at $57.02 \mathrm{Mha}$ (So) (Tab. 8) as EU acreage equivalent, of which 11.2(Si) correspond to soybean and maize imports. The real mobilized area in Europe is in fact $\mathrm{Sm}=$ 57.02-11.2 = 45.82 Mha European crops (E).

So the initial situation is $\mathrm{So}=\mathrm{Sm}+\mathrm{Si}$.

If $\mathrm{R}$ is the reduction ratio of meat consumption, the future situation, keeping the same acreage (which will be used to produce feed and ingredients for "pea meat"), would be:

$$
\mathrm{Sm}=\mathrm{So}-\mathrm{R} \times \mathrm{So}+\mathrm{R} \times \mathrm{Si} \text {. }
$$

Giving $\mathrm{R}=(\mathrm{So}-\mathrm{Sm}) /(\mathrm{So}-\mathrm{Si})=\mathrm{Si} / \mathrm{Sm}=0.244$, or $\quad$ a substitution of $24.4 \%$ of meat by "pea meat". $19.6 \%$

The reduction in "EU acreage equivalent" is $\mathrm{Sm} / \mathrm{So}=$

We may calculate the reduction ratio of meat consumption in a different maner: we know that $1 \%$ reduction in meat consumption allows to spare $0.451 \mathrm{Mha}$ as European acreage equivalent (Tab. 8). To spare 11.2 Mha, the reduction in meat consumption will reach $24.8 \%(11.2 / 0.451=24.8)$

This result is nearly the same with the precision of the calculation.

Meaning that the substitution of about $25 \%$ of the meat consumption by "pea meat" would allow to provide the protein food equivalent with no extension of cultivated acreage in Europe and a cancellation of soybean and maize imports for feed.

We observe that these calculations are neutral regarding the EU exports of animal products, since only EU meat consumption is considered.

\subsubsection{Focus on imported deforestation and land use}

Instead of converting feed needs into European acreages on the basis of European yields, we can now focus on the case of imported ingredients for feed, whose the EU feed protein balance sheet gives an overview (Tab. 6)
Regarding potential deforestation, if we consider direct effects only, the attention should focus on Brazil whose production capacities in extension permit to follow a growing demand in commodities. Soybean meal is the most concerned commodity with a self-sufficiency ratio of only $3 \%$, and at a lesser extent maize (EU imports between 13 to $17 \mathrm{MT} /$ year from 2015 to 2020, almost $60 \%$ from Brazil in 2020). EU imported in 2015/2016 30.2 MT soybean meal for feed. Considering that soybean contains 18 to $20 \%$ oil, and including industrial losses, it corresponds to around 37.8 MT soybeans. According to OilWorld statistics (OilWorld, 2020), the average soybean in Brazil reaches $3.21 \mathrm{t} / \mathrm{ha}$ on the 5 years period 2014-2019. The land acreage needed to provide the soybean meal imported by the EU animal husbandry ranges by 11.8 million ha every year. According to the European Soy Monitor report (IDH and IUCN NL, 2019), only $13 \%$ of the soybean imported in EU in 2017 was guaranteed as deforestation free (and 22\% compliant with FEFAC soy sourcing guidelines). This figure was only $6 \%$ for France in 2017; it would reach 20 to $25 \%$ in $2020-2021$ according to Duralim platform.

The total soybean acreage in Brazil was 34.371 million ha on the same period, meaning that EU feed sector absorbs the equivalent of one third (34.2\%) of the Brazilian soybean production and acreage (or $11.2 \%$ of the world soybean production).

A part of the imported maize should also be taken into account.

\section{Discussion}

\subsection{EU feed consumption and land use}

Concerning pea and rapeseed crops, the basic calculation shows that the development of "pea meat" could induce a significant enhancement of rapeseed oil use in food industry, the impact being limited considering the total land use in EU, 
but much more significant relatively to the size of the rapeseed oil sector itself $(0.512 \mathrm{Mha}$ in the $12.5 \%$ scenario, up to $4 \mathrm{Mha}$ in the $100 \%$ scenario, compared to 6.749 Mha in EU28 in 2017 for a production of $21.9 \mathrm{MT}$; acreages and production decreased since then, mainly due to weather). Synergies between the two pea and rapeseed crops could be developed on both economic and agronomical aspects. For example, previous projects demonstrated that the nitrogen fertilization for a rapeseed crop following peas may be lowered, inducing a better carbon balance and sustainability for rapeseed itself (Véricel et al., 2018)

Less than $12 \%$ of the EU 28 arable land would be needed in case of total substitution, meaning that "pea meat" can be easily absorbed in terms of production capacities. It varies from $9.5 \%$ to $14.4 \%$ in case of pea and rapeseed yields variations of $\pm 20 \%$ (and consequently of protein and oil yields).

This result reflects also the choice of the "pea-meat" model, using pea and rapeseed: other ingredients could be chosen, offering tracks to optimization. If we consider the main component only (pea), variations in protein yield of the different crop sources would give rough estimates of incidence: when pea protein yield ranges by $0.79 \mathrm{t}$ protein/ ha, soybean reaches 0.93 , faba bean 0.98 , when lupin yields only $0.55 \mathrm{t}$ protein/ha, lentils 0.38 , rapeseed 0.69 and sunflower 0.36 (FAO sources reported in Pilorgé and Muel, 2016), meaning a variation on protein yield of approximately $-50 \%$ to $+25 \%$ compared to pea reference. Pea may be considered as a medium case, and acreage optimization would be possible with soybean and faba bean, also traditionally used for food. Lentils would necessitate more acreage but are traditionally consumed without transformation (and inherent losses).

We assumed that $1 \%$ reduction of animal meat consumption leads to $1 \%$ reduction in animal production and feed consumption, which could be a matter of discussion for further scenarios: the economical competition could lead to abandon firstly the less efficient animal production, whose consumption ratios may be higher (specially true for pork and poultry), or, at the contrary in case of meat reduction, the consumer might favor the highest quality of meat for the rest of their consumption, which may lead to less intensive production conditions and to a non-proportional decrease of feed consumption.

When assuming that $1 \%$ reduction applies indifferently to all kinds of meats, beef, pork and poultry, we also implicitly accept a reduction of meat from dairy cows, which can be estimated at about $10 \%$ of the total beef meat production in EU28 (7892 KT total beef production) and less than $2 \%$ of the total EU meat production, all types of meat included. Nevertheless, reducing dairy meat by $1 \%$ would lead to reduce dairy products in the same proportion and that could be compensated by other sources of proteins and fats, except if the cow life duration is extended proportionally (to produce more milk with the same animal). Due to the relatively intensive dairy production in Europe with relatively short dairy cows life, this lever could be used if meat reduction remains limited, probably until $10 \%$ at least. For greater reductions solutions should be found to compensate a drop in dairy production, mobilizing some acreage: our calculation tends to underestimate the acreage necessary to compensate the diminution of meat consumption.
So far we did not comment the reduction of permanent grassland linked to meat substitution, which in fact could reach similar values to arable crops acreage reduction if we apply a $1 \%$ reduction: it must be considered cautiously since these lands are often not proper to cultivation. The alternatives to grazing or hay production might be ecological succession and finally forest in many cases, as often observed. The real interest for carbon storage and biodiversity should be assessed, depending on management policies. If desired for biodiverisity reasons, preserving grassland could also be achieved by using the grass in biogas based energy production thereby reducing methane emissions from ruminants.

The $100 \%$ meat substitution scenario is not to be expected in future due to a partial but structural interdependence between arable crops sector and industries and animal husbandry sector: beyond being a major customer of arable crops commodities, the animal husbandry sector is also a user of many co-products/by-products of food or bio-energies industries which are not further processed for direct human consumption today. The immediate example is in "pea meat" itself: if the direct consumption of grain legumes does not generate co-products, the pea protein extraction starting from peas with 24\% generates around 3 tons of co-product (pea starch and pea solubles) for 1 ton of pea protein isolate $85 \%$. These co-products, already identified but not characterized on the online database Feedipedia (https://www.feedipedia.org) will probably find an outlet in feed industries in the short to medium term whereas in the medium to long term human food alternatives might be developed. Using organic resources not edible by humans, like co-products and fodders, is a traditional role of animal husbandry and contributes to the general balance of agricultural systems.

At last, our calculations did not consider the nutritional aspects to reach well balanced diets, which would be also a limit for the highest substitution rates of vegetable products to animal and would need a significant rebalancing of the diet to meet the requirements in specific nutrients like essential amino-acids and fatty acids. Specific studies like TYFA (Poux and Aubert, 2018, and ongoing works) have focused on the coherence between diets and agricultural production systems, which is a strategic field of investigation.

\subsection{Producing soybean in Europe and ways to reduce dependency to imports}

We show that the substitution of about $25 \%$ of the meat consumption by "pea meat" would allow to provide the protein food equivalent with no extension of cultivated acreage in Europe and a cancellation of soybean and maize imports for feed. This ratio gives a rough estimate of the efforts on food habits with respect to meat consumption to achieve if we wish to reduce imported deforestation without extending the cultivated acreage in Europe. It corresponds to a significant effort (for example 3 to 4 meals per week without meat), but not totally unrealistic if we compare the meat consumption in EU, $68.6 \mathrm{~kg}$ /capita in 2017, (to the FAO statistics (OECD/FAO Outlook 2020-2029, as retail weight) for the 2017-2019 data: $34.5 \mathrm{~kg} /$ capita at world level, $26.6 \mathrm{in}$ developing countries and 69.3 in OECD countries. The $\mathrm{R}$ ratio of 0.25 would lead to $51.5 \mathrm{~kg} /$ capita, still $49 \%$ above the world average. 
Other solutions than soybean production in Europe are also possible to meet the protein needs of animal husbandry in Europe, for example by using wheat and pea as main feed components instead of maize and soybean, better exploiting the diversity of fodder legumes crops or developing grass production in the case of ruminants. Better exploiting the specificities of European regions with the most adapted solutions to both production conditions and consumption patterns is the real challenge, far beyond our simple figures, and need specific studies, notably on feed systems.

A reduction of more than $25 \%$ in meat consumption would lead to a net release of arable land for feeding the European population, which may lead to social and economical consequences for the concerned territories: abandonment of the less fertile lands, planting forests for wood industry or carbon storage, production of biomass for energy or non food uses, or going on with agricultural production for food exports are options that are options that go beyond the agricultural sector alone and involve territorial strategies.

\subsection{Imported deforestation}

Meat is often criticized on two interconnected drawbacks: imported deforestation due to vegetable protein imports, mainly as soybean meal from Brazil, or in other terms the "carbon opportunity cost" (COC) (cf. Hayek et al., 2021), and direct green house gas emissions of the animal production itself, including feed production. We show that the land acreage needed to provide the soybean meal imported by the EU animal husbandry ranges by 11.8 million ha every year in Brazil. According to the European Soy Monitor report (IDH and IUCN NL, 2019), only $13 \%$ of the soybean imported in EU in 2017 was guaranteed as deforestation free (and 22\% compliant with FEFAC soy sourcing guidelines). This figure was only $6 \%$ for France in 2017 ; it would reach 20 to $25 \%$ in 2020-2021 according to Duralim platform. The development of monitoring imported deforestation is an encouraging evolution for Europe, but will hardly reverse the trend at global scale: Europe is becoming a secondary soybean importer, now far behind China.

\section{Conclusions}

A total substitution of meat consumption in EU by plantbased substitutes would mobilize around $12 \%$ of the EU arable land for "pea meat" production, and that a substitution of $25 \%$ of meat consumption would allow to provide the equivalent of food proteins without extending the cultivated areas in Europe, while avoiding soybean and maize imports for feed at the same time.

The Beyond Meat patty must be considered as a case study to evaluate the impacts of meat substitution by vegetable protein food, notably on land use in Europe and abroad, and on the potential synergies between grain legumes and oil crops productions. The direct consumption of grain legumes, as traditionally practiced in many countries, especially in Mediterranean region, is also an alternative which associates significant amounts of grain legumes and unsaturated oils. The impacts of direct consumption of grain legumes are probably similar: most grain legumes are even richer in proteins than the Beyond "pea meat" (18\%).

The relative simplicity of our calculations must not hide the complexity of the substitution of animal meat by vegetable proteins: food systems are made of the interconnected subsystems of the food supply chains under the influence of different drivers like technologies, policies, demography, and socio-cultural aspects as shown in the diagram by Fanzo et al. (2020), where inertia, interdependency and feed-back interactions are numerous. The $100 \%$ substitution scenario is not to be expected in the near future due to a partial but structural interdependence between arable crops sector and industries and animal husbandry sector. Today, feed represents $58 \%$ of the cereal consumption in EU, and 52 to $57 \%$ of the production on 2015-2019 period; oilseeds production is also linked to feed outlets for the valorization of the meals (around $60 \%$ of the tonnage for rapeseed and sunflower). In the mid to long-term perspective these meals might be increasingly utilized in human food consumption.

In fact, animal and crops values chains have strong connections from land use and agronomy to the products valorization, with both synergies and competitions for resources especially land or markets for meat, vegetable proteins, milk or soy products. Thinking transitions and coevolutions is preferable to thinking substitutions only. Even if the excessive meat consumption in Europe is a source of disequilibrium (for example, only $2 \%$ of grain legumes in European arable acreage when $6 \%$ is observed in Canada), regarding land use and agronomy, the main problems come more from the disconnection between animal husbandry and crops, permitted by the huge amounts of vegetable protein imports as soybean meals, leading to a growing specialization of cropping systems and heavy impacts on nitrogen and nutrients cycles (Billen et al., 2014) than from a real competition for local resources. Reaching sustainable food systems will need new balances between animal and vegetable consumption and production in future. Important synergies could be developed also with the oilseed sector in Europe. At last, "pea meat" and more generally vegetable proteins for food form an important lever to decrease imported deforestation and improve the sustainability of the European food system.

Acknowledgements. This work was carried out as part of the LegValue project. The project was funded by the European Union in the Horizon 2020 programme under number 727672.

\section{References}

AGT. 2020. PulsePlus protein. Available from http://agtfoods.com/ products/pulseplus-protein.html (last consult.: 16/01/2020).

Aiking H, de Boer J. 2020. The next protein transition. Trends Food Sci Technol 105: 515-522.

ANSES. 2020. French food composition table. http://ciqual.anses. fr/\#.

Baldwin A, Zahradka P, Weighell W, Guzman RP, Taylor CG. 2017. Feasibility and tolerability of daily pulse consumption in individuals with peripheral artery disease. Can J Diet Pract Res 78(4): 187-191. 
Beyond Meat. 2019a. The Beyond Burger. List of ingredients on packaging.

Beyond Meat. 2019b. The future of protein. Available from www. beyondmeat.com (last consult.: 07/06/2019).

Beyond Meat. 2020. Beyond Meat and Roquette announce multi-year pea protein supply agreement. Available from https://www. globenewswire.com/news-release/2020/01/14/1970583/0/en/Be yond-Meat-and-Roquette-Announce-Multi-Year-Pea-ProteinSupply-Agreement.html (last consult.: 18/01/2020).

Billen G, Lassaletta L, Garnier J. 2014. A biogeochemical view of the global agro-food system: nitrogen flows associated with protein production, consumption and trade. Glob Food Secur 3: 209-219. https://doi.org/10.1016/j.gfs.2014.08.003i.

Bloomberg. 2019. The mighty pea is everybody's new favorite plantbased protein. Available from www.bloomberg.com (last consult.: 07.06.2019).

Dahl WJ, Foster LM, Tyler RT. 2012. Review of the health benefits of peas (Pisum sativum L.). Br J Nutr 108(S1): S3-S10.

Dreher J, Blach C, Terjung N, Gibis M, Weiss J. 2020. Formation and characterization of plant-based emulsified and crosslinked fat crystal networks to mimic animal fat tissue. J Food Sci 85(2): 421-431.

Emsland. 2015. Neue Ansätze zur Vermarktung von Leguminosen. 3. Ackerbautagung des Deutschen Bauernverbandes. Berlin, 13 Mai 2015.

European Commission. 2019. EU 28 balance sheet for protein feed 2017/18. https://ec.europa.eu/info/news/commission-publishesoverview-eu-feed-supply-2019-may-20_en (last consult: 12.2020)

Fanzo J, Drewnowski A, Blumberg J, Miller G, Kraemer K, Kennedy E. 2020. Nutrients, foods, diets, people: Promoting healthy eating. Curr Develop Nutr 4(6): nzaa069. https://doi.org/10.1093/cdn/ nzaa069.

FEFAC. 2018. Statistical yearbook 2018 and statistics website. Available from https://old.fefac.eu/our-publications/statistics/.

Figueira N, Curtain F, Beck E, Grafenauer S. 2019. Consumer understanding and culinary use of legumes in Australia. Nutrients 11(7): 1575 .

Flysjö A, Cederberg C, Henriksson M, Ledgard S. 2011. How does co-product handling affect the carbon footprint of milk? Case study of milk production in New Zealand and Sweden. Int J Life Cycle Assess 16(5): 420-430. https://doi.org/10.1007/ s11367-011-0283-9.

Foyer CH, Lam HM, Nguyen HT, et al. 2016. Neglecting legumes has compromised human health and sustainable food production. Nat Plants 2(8): 1-10.

Guilpart N, Iizumi T, Makowski D. 2020. Data-driven yield projections suggest large opportunities to improve Europe's soybean self-sufficiency under climate change. bioRxiv Preprint. https://doi.org/10.1101/2020.10.08.331496.

Hamann K. 2019. Ten example business-cases on the successful marketing of legumes as food. Deliverable D4.2. TRUE-project.

Hayek MN, Harwatt H, Ripple WJ, Mueller ND. 2021. The carbon opportunity cost of animal-sourced food production on land. Nat Sustain 4: 21-24.

Heller MC, Keoleian GA. 2018. Beyond Meat's Beyond Burger life cycle assessment: A detailed comparison between a plant-based and an animal-based protein source. Regents of the University of Michigan.

IDH, IUCN NL. 2019 European soy monitor. Researched by B. Kuepper and M. Riemersma of Profundo. Coordinated by N. Sleurink of IDH, The Sustainable Trade Initiative and H. van den Hombergh of IUCN National Committee of the Netherlands.
Joshi VK, Kumar S. 2015. Meat analogues: Plant based alternatives to meat products - A review. Int J Food Ferment Technol 5(2): 107.

Kezeya Sepngang B. 2019. Detailed flow of goods for legumes from seed production to end use in three European countries. Quantified schematic representations of resources, use and trends in German, France and the UK. Available from www.legvalue.eu/ publications (last consult.: 27/07/2019).

Kuhlman T, Helming JFM, Oudendag D. 2014. Policy impacts on legume-based agriculture at EU level. Paper prepared for presentation at the EAAE 2014 Congress "Agri-Food and Rural Innovations for Healthier Societies”, 26-29 August, 2014, Ljubljana, Slovenia.

Lim XX, Koh WY, Uthumporn U, Maizura M, Wan Rosli WI. 2019. The development of legume-based yogurt by using water kefir as starter culture. Int Food Res J 26(4).

Lopes M, Pierrepont C, Duarte CM, Filipe A, Medronho B, Sousa I. 2020. Legume beverages from chickpea and lupin, as new milk alternatives. Foods 9(10): 1458.

Mackenzie SG, Leinonen I, Kyriazakis I. 2017. The need for coproduct allocation in the life cycle assessment of agricultural systems - Is "biophysical" allocation progress? Int J Life Cycle Assess 22(2): 128-137.

Madar Z, Stark AH. 2002. New legume sources as therapeutic agents. Br J Nutr 88(S3): 287-292.

Magrini MB, Anton M, Chardigny JM, et al. 2018. Pulses for sustainability: breaking agriculture and food sectors out of lockin. Front Sustain Food Syst 2: 64.

Magrini MB, Cabanac G, Lascialfari M, et al. 2019. Peer-reviewed literature on grain legume species in the WoS (1980-2018): A comparative analysis of soybean and pulses. Sustainability 11(23): 6833 .

Murphy-Bokern D, Dauber J, Rittler L, et al. 2019. Translating knowledge for legume-based farming for food and feed (legumes translated). In: First European Conference on Crop Diversification, p. 51.

Nawaz MA, Tan M, Øiseth S, Buckow R. 2020. An emerging segment of functional legume-based beverages: A review. Food Rev Int 1-39.

OECD/FAO. 2020. OECD-FAO agricultural outlook 2020-2029. Rome: FAO; Paris: OECD Publishing. https:/doi.org/10.1787/ 1112 c23b-en.

OilWorld. 2020. ISTA Mielke GMBH. OilWorld Annual 2020. Global analysis of all major oilseeds, oils and oil meals. Supply, demand and pricne outlook.

Pilorgé E, Muel F. 2016. What vegetable oils and proteins for 2030 ? Would the protein fraction be the future of oil and protein crops? OCL 23(4): D402. https://doi.org/10.1051/ocl/2016030.

Poux X, Aubert P-M. 2018. An agro-ecological Europe in 2050: Multifunctional agri-culture for healthy eating. Findings from the ten years for agroecology (TYFA) modelling exercise. Paris, France: Iddri-AScA, study No. 09/18, 74 p.

Qamar S, Manrique YJ, Parekh H, Falconer JR. 2019. Nuts, cereals, seeds and legumes proteins derived emulsifiers as a source of plant protein beverages: A review. Crit Rev Food Sci Nutr 1-21.

Reuters. 2019. Beyond Meat to start plant-based meats production in Europe next year. Available from https://www.reuters.com/ article/us-beyond-meat-europe-idUSKCN1SY1G1 (last consult.: 07/06/2019).

Röös E, Carlsson G, Ferawati F, et al. 2018. Less meat, more legumes: Prospects and challenges in the transition toward sustainable diets in Sweden. Renew Agric Food Syst 1-14.

Schmidt H, Philips L, Welsh JP, Fragstein PV. 2012. Legume breaks in stockless organic farming rotations: nitrogen accumulation and 
influence on the following crops. J Biol Agric Horticult 17(2): 159-170. https://doi.org/10.1080/01448765.1999.9754835.

Schott C, Mignolet C, Meynard J-M. 2010. Les oléoprotéagineux dans les systèmes de culture: évolution des assolements et des successions culturales depuis les années 1970 dans le bassin de la Seine. OCL 17(5): 276-291. https://doi.org/10.1051/ ocl.2010.0334.

Sha L, Xiong YL. 2020. Plant protein-based alternatives of reconstructed meat: Science, technology, and challenges. Trends Food Sci Technol.

Singhal A, Karaca AC, Tyler R, Nickerson M. 2016. Pulse proteins: from processing to structure-function relationships. Grain Legum 55.

Trinidad TP, Mallillin AC, Loyola AS, Sagum RS, Encabo RR. 2010. The potential health benefits of legumes as a good source of dietary fibre. Br J Nutr 103(4): 569-574.
Turfani V, Narducci V, Durazzo A, Galli V, Carcea M. 2017. Technological, nutritional and functional properties of wheat bread enriched with lentil or carob flours. LWT 78: 361-366.

van der Weele C, Feindt P, van der Goot AJ, van Mierlo B, van Boekel M. 2019. Meat alternatives; an integrative comparison. Trends Food Sci Technol.

Véricel G, Dubois S, Duval R, et al. 2018. Impact de l'introduction des légumineuses dans les systèmes de culture sur les émissions de protoxyde d'azote. Innov Agron 63: 211-229.

Verni M, Demarinis C, Rizzello CG, Baruzzi F. 2020. Design and characterization of a novel fermented beverage from lentil grains. Foods 9(7): 893.

Wobser T. 2018. Ratgeber Förderung. Der Antrag: Was gibt es neues. Wochenblatt für landwirtschaft und Landleben. Kompakt, pp. 6.

Cite this article as: Pilorgé E, Kezeya B, Stauss W, Muel F, Mergenthaler M. 2021. Pea and rapeseed acreage and land use for plant-based meat alternatives in the EU. OCL 28: 54 